This PDF is a selection from an out-of-print volume from the National Bureau of Economic Research

Volume Title: Import Competition and Response

Volume Author/Editor: Jagdish N. Bhagwati, editor

Volume Publisher: University of Chicago Press

Volume ISBN: 0-226-04538-2

Volume URL: http://www.nber.org/books/bhag82-1

Publication Date: 1982

Chapter Title: The Political Economy of Protectionism

Chapter Author: Robert E. Baldwin

Chapter URL: http://www.nber.org/chapters/c6008

Chapter pages in book: (p. 263 - 292) 


\title{
10 \\ The Political Economy of Protectionism
}

\author{
Robert E. Baldwin
}

Although economic historians have traditionally studied international trade policies in both economic and political terms, it has only been within the last decade that trade economists have manifested much more than casual interest in this approach. ${ }^{1}$ Over a dozen articles or papers have been written since 1974 in which trade economists have analyzed in quantitative terms the relationship between the level of protection (or a change in the level) afforded different industries or income classes and various political and economic characteristics of these sectors or groups that appear to influence the level of protection. ${ }^{2}$ This greater attention to the political economy of protectionism is only one indication of the growing interest by economists in public choice-a subject that Mueller (1976) defines as the application of economics to political science. According to Mueller public choice developed as a separate field in response to the issues raised by Bergson (1938), Samuelson (1947), and Arrow (1951) in their pioneering work on social welfare and also in response to the explorations in the 1940s and 1950s of the conditions in which the free market mechanism fails to achieve a Pareto-optimum allocation of resources.

Robert E. Baldwin is the F. W. Taussig Research Professor of Economics at the University of Wisconsin-Madison. Among his recent articles is "Welfare Effects on the United States of a Significant Multilateral Tariff Reduction" (with J. H. Mutti and J. D. Richardson), Journal of International Economics, August 1980. His study The Political Economy of U.S. Import Policy will be published in 1983.

The author is grateful for the valuable comments of the discussants and other conference participants and especially for Jagdish Bhagwati's help in tightening up the paper. Thanks are due to the Office on Foreign Economic Research, United States Department of Labor, and the World Bank for financial support in undertaking the research underlying this paper. 


\subsection{Welfare Economics: Bergson, Samuelson, Arrow, et al.}

A discussion of the political economy of trade policy can usefully begin by placing the subject in the framework established by Bergson and Samuelson for analyzing social welfare. The Bergson-Samuelson formulation of the social welfare function makes a clear-cut distinction between individual tastes or preferences for goods and services and individual values relating to general standards of equity or to other ethical judgments. These authors also assume that an individual's preferences for economic goods and services depend only upon his own consumption of these items and not upon what other individuals consume. Thus social welfare $(W)$ is written as

$$
\begin{aligned}
W= & W\left[U^{1}\left(X_{1}^{1}, \ldots, X_{n}^{1} ; V_{1}^{1}, \ldots, V_{m}^{1}\right), \ldots\right. \\
& \left.U^{s}\left(X_{1}^{s}, \ldots, X_{n}^{s} ; V_{1}^{s}, \ldots, V_{m}^{s}\right)\right]
\end{aligned}
$$

where the $U$ terms represent ordinal utility measures for the $s$ individuals, the $X$ terms stand for the $n$ commodities, and the $V$ terms stand for the $m$ productive services.

As Samuelson points out, the social welfare function characterizes some set of ethical beliefs that permits an unequivocal answer as to whether one configuration of the economic system is "better" than, "worse" than, or "indifferent" to any other. ${ }^{3}$ Bergson also stresses that the social welfare function rests on ethical criteria. ${ }^{4}$ Neither author analyzes in any detail the nature of the value judgments nor how the community selects a particular social welfare function. Bergson utilizes an egalitarian welfare function to indicate how a maximum welfare position would be determined, but he points out that any set of value propositions sufficient to evaluate all alternatives could be used. He states that the determination of prevailing values for a given community is a proper and necessary task for economists but does not pursue this topic at all himself. ${ }^{5}$ With regard to the manner of selection of the welfare function, Bergson simply assumes - as Arrow notes-that there is a universally accepted ordering of different possible welfare distributions in any situation. ${ }^{6}$

The manner in which the social welfare function is used to determine a maximum social welfare point under a given set of economic circumstances is illustrated in figure $10.1^{7}$. Letting $U^{1}$ and $U^{2}$ be ordinal utility indices for individuals 1 and 2 (assumed for simplicity to be the entire community), suppose that the curve $A A^{\prime}$ represent the free trade utilitypossibility function for the community with its given set of individual preferences, factor supplies, and technical production constraints. The necessary (but not sufficient) conditions for maximizing social welfare are the familiar Pareto-optimum conditions of production and exchange, and 


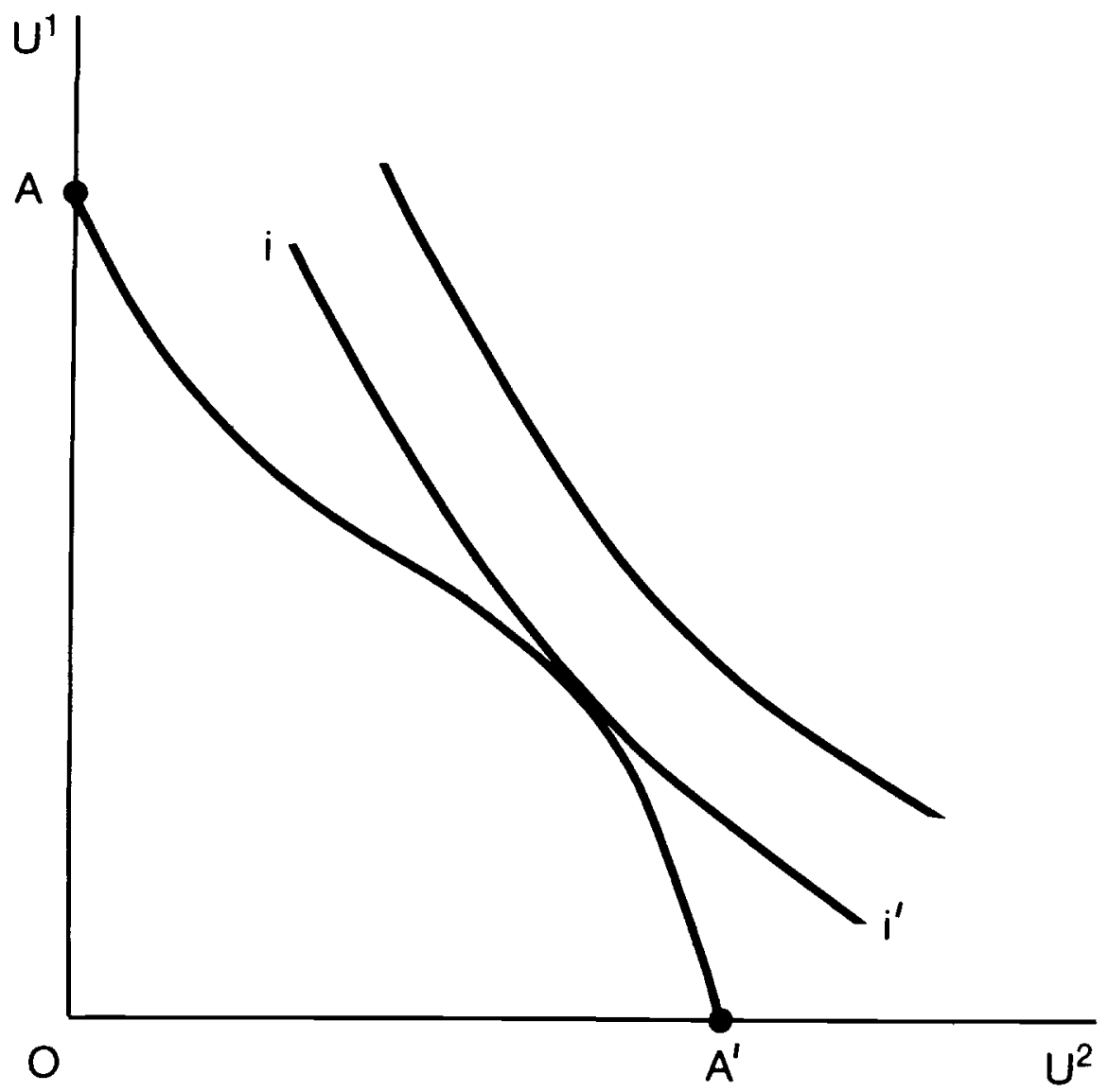

Fig. 10.1

these enable one to reduce the level of indeterminacy in the system to points along the utility-possibility frontier. Next, the social welfare function is depicted in the figure by means of a set of social indifference contours, along any one of which, e.g., $i i^{\prime}$, social welfare is constant. Since individuals are assumed to "count," the indifference contours cannot intersect and must slope downward, although their absolute slopes at any point are arbitrary. Obviously social welfare is maximized at the point of tangency between a social welfare contour and the utilitypossibility curve. At the tangency point it is ethically judged that the marginal social utility of income (or of any commodity) is the same for the two individuals.

Arrow defines the social welfare function somewhat differently from Bergson and Samuelson. He first points out that the distinction between tastes and ethical values is by no means clear-cut. ${ }^{8}$ To use his examples, 
there is little difference between the pleasure derived from one's own lawn and from one's neighbor's lawn or between an individual's dislike of having his grounds ruined by factory smoke and his distaste for the existence of heathenism in some distant area. Consequently, Arrow views each individual as ordering not only the various amounts of each type of commodity he may consume as well as of the labor he may supply but the amounts of both private and collectively consumed goods in every one else's hands. Each of these distributions of goods and services, i.e., each social state, is also ordered as directly represented rather than by using the notion of a utility function. He then defines a social welfare function as a process or rule which, for each individual ordering of alternative social states, gives a corresponding social ordering of these social states. ${ }^{9}$ As Arrow points out, whereas Bergson seeks to locate social values in welfare judgments by individuals, he locates them in the actions taken through the rules society uses for making social decisions. ${ }^{10}$

The problem posed by Arrow on the basis of this definition of a social welfare function is whether a rule exists for passing from individual orderings of social states to a social ordering without violating such reasonable conditions as that the rule not be imposed or dictatorial and that it give a consistent ordering of all feasible alternatives. He discovered that in general it was not possible to find such a rule. Majority voting, for example, can lead to results that violate the transitivity condition. Only if at least a majority of individuals have the same ordering of social alternatives or if individual orderings are single-peaked will majority voting always produce a social ordering that meets these conditions.

An advantage of the Bergson-Samuelson formulation of welfare economics is that there is scope for the economist to make policy recommendations without it being necessary to inquire into a community's ethical standards or to know the process by which these standards are implemented. If a particular policy, e.g., free trade, gives a situation utility-possibility function entirely outside another policy, e.g., no trade, then the first policy will yield a point on a higher social welfare contour than the second policy no matter what the shape of the social welfare contours. Since, however, the implementation of a particular policy places the economy at some specific point on a situation utility-possibility function, redistributions of welfare along such a function must be permitted for this statement to have validity.

\subsection{The Positive Theory of Trade Policy Determination}

The contributions of Bergson, Samuelson, and Arrow prompted the developments that led, in particular, to the consideration of the related but distinct theory of public choice. In particular, the question was raised 
whether Pareto-efficient resource-allocational policies, delineated as such by economic analysis, would in fact be adopted under the political processes characterizing modern industrial democracies.

Writers pursuing the latter line of thought, e.g., Downs (1957) and Buchanan and Tullock (1962), postulate that voters and their elected representatives pursue their own self-interest in the political marketplace just as they do in the economic marketplace. The difference is that preferences are expressed by ballot box voting rather than dollar voting.

In applying this approach to trade policy, economists generally hypothesize producers and particular income groups to be the demanders of protectionism who seek to maximize the present value of the additional income they can obtain by reducing imports. Elected representatives (or the citizens themselves, if there is direct voting) are regarded as the suppliers of protection who also seek to maximize their own welfare. Under conditions of perfect competition in political markets this implies that they maximize their chances of election.

\subsubsection{Perfect Markets}

An important conclusion from this economic approach to political decision making is that Pareto-efficient policies will be implemented under majority rule provided that such conditions prevail as perfect information, no voting costs, and the absence of any costs of redistributing income.$^{11}$ Suppose, for example, that the foreign offer curve facing a country shifts outward and thereby enables the country to expand its consumption possibilities. In a vote between a tariff policy that restricts the consumption possibilities to its initial set and a free trade policy that enlarges this set, the latter policy will be selected, since it is possible to make a majority of voters (or even all voters) better off under the free trade policy than they are initially. However, in selecting a particular point among the many on the free trade utility-possibility frontier on the basis of majority rule, the cycling problem noted by Arrow can arise for the community. Each individual will order the alternative social states along this frontier on the basis of the utility he obtains from each. However, while individual preferences are transitive, majority voting will not in general yield transitive social preferences. If all points on the utility-possibility functions are to be considered, the only way out of the difficulty without abandoning majority rule is, as Arrow has shown, either to assume a universally-agreed-upon ordering of all welfare distributions (the Bergson approach) or at least to assume that a majority of voters possess identical orderings of these distributions. The latter approach means that the social welfare function is dictatorial; on the other hand, in accepting majority voting as the selection rule, the condition of nondictatorship loses its intrinsic desirability. ${ }^{12}$ 


\subsubsection{Redistribution Limitations}

Those who apply public choice theory to trade policy generally rule out the possibility of redistribution along a utility-possibility frontier. They assume in their analyses that the selection of a particular point on the frontier results from the operation of market forces as modified by trade taxes and as influenced by individual tastes and the prevailing distribution of productive factors. ${ }^{13}$ This, for example, is the framework in which the Stolper-Samuelson (1941) theorem is sometimes utilized to account for protectionism in a capital-abundant economy. Since in the standard Heckscher-Ohlin-Samuelson trade model with two factors (capital and labor), two goods, and fixed trading terms a tariff will raise the real return to labor, protectionism will emerge if workers have more voting power than capitalists. ${ }^{14}$

But labor could always improve any position it attains under protectionism by permitting free trade and then redistributing income in its favor through lump-sum taxes that it could impose by majority voting. However, this possibility usually is not mentioned in discussing this application of economics to the politics of protection. Likewise, writers who analyze protection to particular industries and who assume that factors are industry-specific in the short run, generally do not introduce the possibility of free trade coupled with lump-sum redistribution to the factors in the industry as an option to be explained.

While most countries have some forms of automatic compensation to factors adversely affected by imports such as extended unemployment compensation, retraining payments, migration allowances, technical assistance, and governmental purchasing and scrapping of excess capital equipment, they usually do not fully compensate for the economic loss to these factors. Moreover, the measures are used to supplement protection from imports that takes the form of higher duties or quotas rather than to substitute for protectionism. Just why this is so is itself an important topic for investigation within a political economy framework. Some comments are made about this matter in the next section when discussing possible extensions of the usual analysis. The point here is simply that although the assumption made by previous writers in this field concerning limited redistribution possibilities may be consistent with the actual policies of most governments, it is a severe restriction upon first-best welfare analysis.

\subsubsection{Information and Voting Costs}

Besides generally ruling out the possibility of income redistribution within the context of free trade or protectionism, writers in the field also focus on the existence of various other imperfections in political markets that prevent a complete expression of the preferences of the population 
through the voting process. Information costs and costs of registering one's preferences through the voting process are two sources of such imperfections.

For example, in an environment of imperfect information some consumers may be unaware that the prices of an imported product and its domestic substitute have risen in response to a higher import duty. Moreover, if the increase in prices is modest compared with their budget outlays on the items, it may not be rational for these consumers to invest the time and funds to find out about the cause of the price rises in order to try to reverse these increases through the political process. Even if a consumer is aware of the reason for the price increases, he may find that the costs of registering his opposition through the political process are greater than his resultant loss in consumer welfare.

The existence of these types of costs together with the point that the welfare losses from protecting a particular industry are so widely dispersed that the loss to any one consumer is small were first emphasized by Downs (1957) as an explanation of why producers succeeded in obtaining protection from imports.

\subsubsection{Elected Representatives and Political Parties}

Another type of imperfection in political markets introduced in the literature on the subject concerns the fact that representative democracy with political parties prevails rather than direct democracy. If political markets operate perfectly, the actions of elected officials will merely reflect the wishes of the voters. For otherwise new candidates will enter the market and unseat existing representatives of the voters. However, the existence of imperfections that provide incumbents with special election advantages and make it very costly for new candidates to make their views widely known modifies this conclusion and increases the possibility that the wishes of a majority of the voters will not be carried out.

Brock and Magee $(1974,1980)$ have utilized game theory to analyze the manner in which one political party selects a particular trade policy and how a second party reacts to this choice. For example, they pose the problem of choosing preelection tariff positions by a protariff and a free-trade party in the following way. The protariff party maximizes its probability of election by increasing the level of protection it supports until the positive marginal effect on the party's election probability from the increased resources given by the protectionist lobby is just offset by the negative effect of lost voters and resource flows from free traders to the free-trade party. The free-trade party, on the other hand, chooses a position that minimizes the election chances of the protectionist party. Thus it will lower its tariff below the other party's tariff until the marginal positive effect on its election probability from resources and votes provided by free traders is just offset by the negative impact of increased 
funds flowing from the protectionist lobby to the protariff party. Assuming equilibrium is of the simple Cournot-Nash variety, they are able to derive such results as: (1) In the neighborhood of equilibrium, one party will become more protectionist when the second does, but the second party will adopt a more liberal position when the first party becomes more protectionist. (2) If the protectionist lobby becomes more powerful, it is not inevitable that both parties will become more protectionist; one of the parties may favor a lower tariff.

\subsubsection{The Free-Rider and Externality Problems}

Still another type of imperfection in the operation of politicaleconomic markets emphasized by writers in this field, e.g., Olson (1965) and Pincus $(1972,1975)$, is the free-rider problem that is associated with the provision of a public good. A tariff (or the absence of one) has the characteristic of a public good in that a beneficiary from a tariff cannot be excluded from the benefits, even though he does not contribute to the costs of providing the tariff. For example, a firm in a protected industry benefits even if it does not contribute to the lobbying efforts required to secure the protection. Thus there is an incentive for each firm not to reveal its true preferences regarding its benefits in the hope that others will pay the lobbying costs. Olson argues that the voluntary formation of an effective lobbying group is more likely if the group is small and if the benefits are unevenly distributed, since under these circumstances the benefits to each individual member, or at least one member, increase. ${ }^{15}$ Pincus adds that the costs of coordinating and monitoring a pressure group tend to reduce lobbying activity if an industry is widely dispersed geographically.

This framework has been applied to explain both why protectionism exists despite the fact that consumers represent a majority of voters as well as why some industries are more highly protected than others. Consumers are too numerous and widely dispersed for effective liberaltrade pressure groups representing their interests to be formed. While these factors generally do not prevent producers from organizing into pressure groups, one does expect that pressure groups will be more effective if the industries they represent are characterized by high levels of firm and geographic concentration. However, Olson notes a possible exception. Some groups provide both private and public goods and collect funds for organizing and lobbying from the sale of the private good. For example, a group may sell a magazine or journal that provides helpful technical information to its members. Consequently, even though the structure of an industry appears unfavorable for organizing into an effective pressure group, it may in fact be well organized for this reason. ${ }^{16}$

While a tariff has the public good characteristic that all producers in a protected industry benefit from the higher price no matter whether they 
do or do not contribute to the costs of obtaining protection, it lacks the characteristic of a pure public good that increases in benefits to one producer do not reduce the benefits to other producers. The producer benefits from protection mainly take the form of temporary rents, although expansion in the protected sector may also increase long-run returns to some factors. The distribution of these benefits among existing producers depends upon how rapidly and to what extent they respond on the supply side as well as on how fast new domestic competitors take advantage of the enhanced profit opportunities. In deciding how much to invest in lobbying activities, an individual producer must estimate the supply response of others as well as his own in order to be sure he earns at least the market rate on his rent-seeking investment. Even if there is only one producer, he must be concerned with the possibility that his lobbying investment will create profit opportunities so attractive that other firms will enter the market and prevent him from earning an acceptable return on his lobbying activities. In other words, just as a protective duty is no guarantee that individual entrepreneurs in an infant industry will undertake greater investments in acquiring technological knowledge, so too is the existence of net benefits from lobbying not a guarantee that the rent seeking will be undertaken.

This externality problem may in part explain why protectionist efforts over the last fifty years have usually focused on depressed industries. It is not rational for capitalists outside such an industry or even within the industry to invest in new productive capacity nor for outside workers to seek employment in the sector if a tariff increase occurs that still leaves the rate of return on investment and the wage rate below what they are generally. Those involved in such an industry know that the distribution of rents on existing physical and human capital in the industry is likely to be closely related to existing factor supplies and can be more certain of their return from such a tariff.

\subsection{Modifying the Positive Theory of Trade Policy Determination: Social Values and Interpersonal Effects}

The public choice theory of trade policy determination reviewed above is based on the assumptions that all individuals in the economy seek to maximize their welfare and that individual welfare depends only upon the goods and services a person consumes directly.

However, it is evident that considerations of equity and social justice may well affect policy choices. Thus the fact that low-income workers, including women and migrants, are substantially employed in textiles may account partly for the protection granted to this industry in some of the developed countries. The desire to protect the incomes of the underprivileged groups, whether defined by sex or citizenship or by regional 
location (e.g., depressed regions), can thus well provide an input into the tariff-making process, though, it must be stressed, this does not in itself explain the choice of tariff protection rather than other policy instruments in granting this element of redistribution to the concerned group.

Among the many studies of tariff making or tariff reduction that have stressed this issue, one may include Cheh (1974), Caves (1976), Helleiner (1977), and Anderson (1978). Corden (1974, p. 107) has suggested that societies may have a "conservative welfare function" which requires that trade policy should be implemented so as to avoid "any significant reductions in real incomes of any significant section of the community."

If altruistic notions do contribute to protection, one may well ask what prompts such altruism. Arrow (1975) gives three reasons why an individual undertakes actions that are, or seem to be, expressions of altruism. First, the welfare of the individual may depend not only on the goods he consumes but also on the economic welfare of others. An altruistic relationship exists if the individual's welfare decreases when the welfare of others decreases. ${ }^{18}$ As will be recalled, interpersonal relationships of this type are excluded from the Bergerson-Samuelson formulation of the social welfare function, though not from Arrow's. Second, not only may the individual derive satisfaction from seeing someone else's satisfaction increased, but also he may gain satisfaction from the fact that he himself has contributed to that satisfaction. Third, an individual may be motivated entirely by his own egotistic satisfaction, but "there is an implicit social contract that each performs duties for others in a way calculated to enhance the satisfaction of all"-an argument that implies enlightened self-interest. ${ }^{19}$

Of these reasons for altruistic behavior, the last may have particular relevance to protectionist policies. Thus it may be that an individual supports a tariff increase outside his own industry because he thinks this action will enhance his own chances of receiving tariff protection should his industry come under severe import competition in the future. It is this idea that serves as the basis for regarding tariffs as a type of insurance policy (see Corden 1974, pp. 320-21; Cassing 1980, pp. 396-97). Workers and capitalowners who are risk-adverse wish to avoid human and physical capital losses due to sudden and significant increases in imports that compete with the domestic products they produce. However, private markets to insure against this risk fail to exist, apparently for reasons of inadequate data or "moral hazard." The import relief legislation involving recommendations from the International Trade Commission can, for example, be viewed as a means of providing the desired insurance. However, if this view is adopted, one is left guessing why the implicit contractual behavior agreed upon by different industry groups chooses tariffs as the method of providing relief against import competition since this policy leaves consumers worse off and thereby reduces the scope of 
the implicit contractual arrangements embracing other groups with a political role.

Moreover, protection may well reflect broader goals, such as those analyzed by Johnson (1960) in his seminal analysis of the "scientific tariff" where he analyzed the optimal tariff structure to promote collective goals such as industrialization, self-sufficiency, "a way of life," and military preparedness. ${ }^{20}$ While Johnson considers the question of optimal tariff structures to reflect these goals at minimal cost, the question as to whether protection or alternative policy interventions will be the leastcost policies to adopt in pursuit of such goals is explored in other papers by Johnson (1965) and Bhagwati and Srinivasan (1969).

That altruism, a Bergsonian approach, and the pure public-choicetheoretic solution can result in different tariff outcomes may now be simply illustrated. Thus, in figure $10.2, A B$ is the production possibility curve for goods $X_{1}$ and $X_{2}$. A shift in the terms of trade of this small, open $2 \times 2$ economy will shift production from $P$ to $P_{0}{ }^{*}$. The optimal solution, in Paretian economic terms, is then at $P_{0}{ }^{*}$ with zero tariff. It is also the pure public-choice-theoretic majority-rule solution under the ideal restrictions set out in section 10.2. But suppose now that there is an "altruistic," "empathetic" feeling toward labor in this model. And depict the real wages of labor in the lower RHS quadrant. There, as the production of $X_{1}$ (the $K$-intensive good) falls with the imposition of successively higher tariffs which raise the relative price of good $X_{2}$, the real wages of labor rise à la the Stolper-Samuelson theorem. Therefore an "altruistic" tariff $\left(t_{A}\right)$ may be depicted as that which brings production to $P_{A}$ and real wages up from $W_{0}$ to $W_{A}$. On the other hand, one may envisage a government which instead maximizes a quasi-Bergson social welfare function such as that represented in the lower LHS quadrant. This social welfare function is defined directly on wage and rental incomes in the $2 \times 2$ model, rather than on the utilities of the wage and rental earners as in the classic Bergsonian social welfare function. The tangency of the social indifference contour with the wage-rental locus in the lower LHS quadrant then determines the corresponding production at $P_{B}$ and the associated "Bergsonian" tariff rate $t_{B} \cdot{ }^{21}$

\subsection{Lobbying-determined Protection Reflecting Foregoing Considerations}

The degree of protection resulting from the foregoing considerations can be formally analyzed along the lines of figure 10.3. Let $0 t_{0} V$ be the "cost of lobbying" curve, reflecting the dollar cost of securing increasing levels of tariff protection by a lobby. Such a curve will reflect factors such as that the willingness of elected officials to grant additional protection to an industry is (1) inversely related after a point to the degree of protec- 


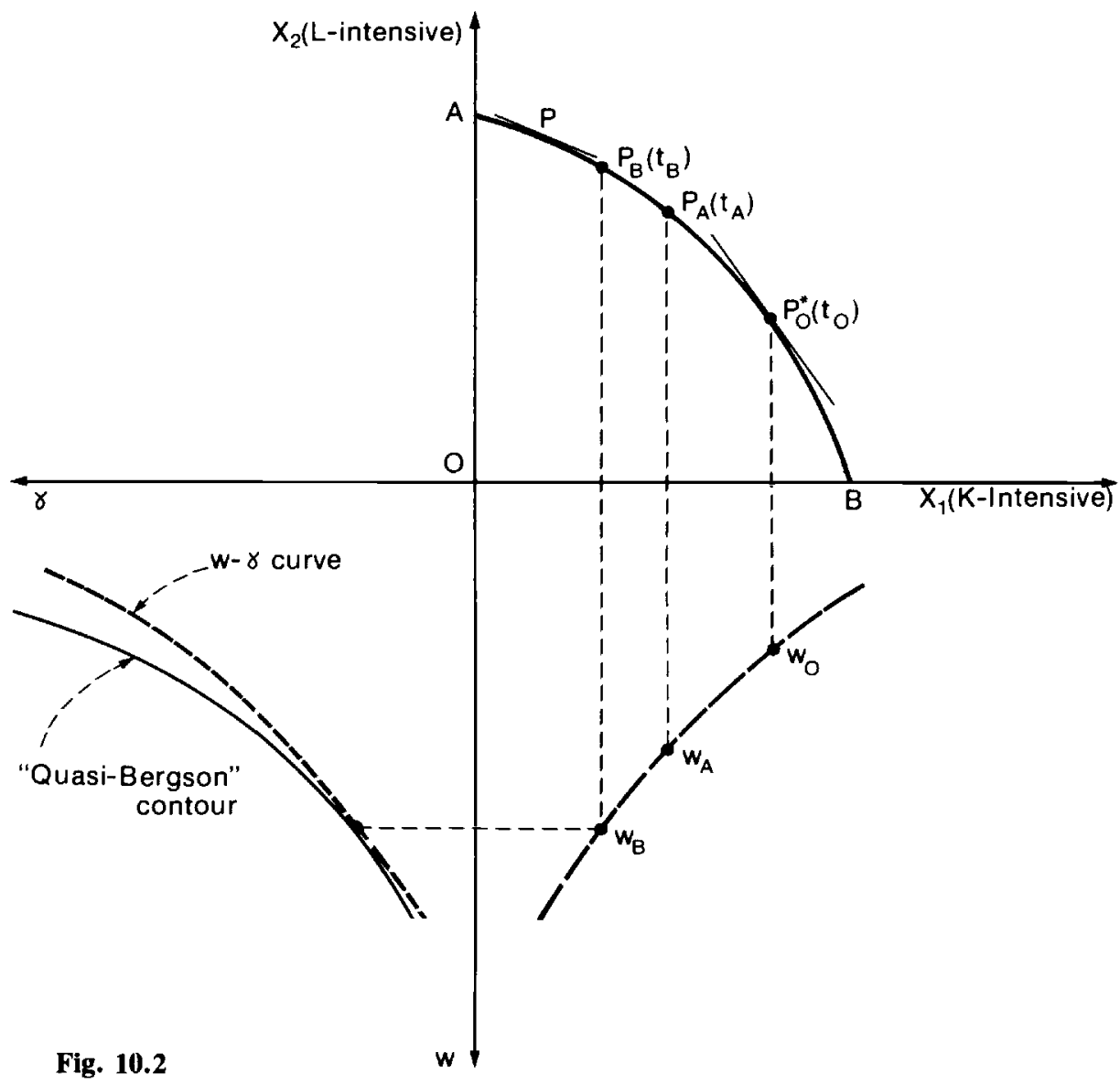

tionism already given to the industry; (2) positively associated with the magnitude of producer lobbying expenditures (both of these relationships are part of the Brock-Magee model); and (3) positively correlated with the degree to which economic conditions in the industry match either the altruistic values or the social insurance desires of the voters. Not only are industry lobbying funds provided to candidates so that voters can be informed about how they have been, or will be, helped by the candidates, but also they are spent by an industry to convince voters that the industry's condition or cause of injury merits assistance on such grounds as fairness and equity. In other words, lobbying funds deployed by an industry will tend to reflect, in varying degrees, the diverse factors that have been discussed earlier in this paper. Reflecting the fact therefore that altruism may result in some protection at zero or negligible cost, the $0 t_{0} V$ curve has the stretch $0 t_{0}$ along the horizontal axis. 


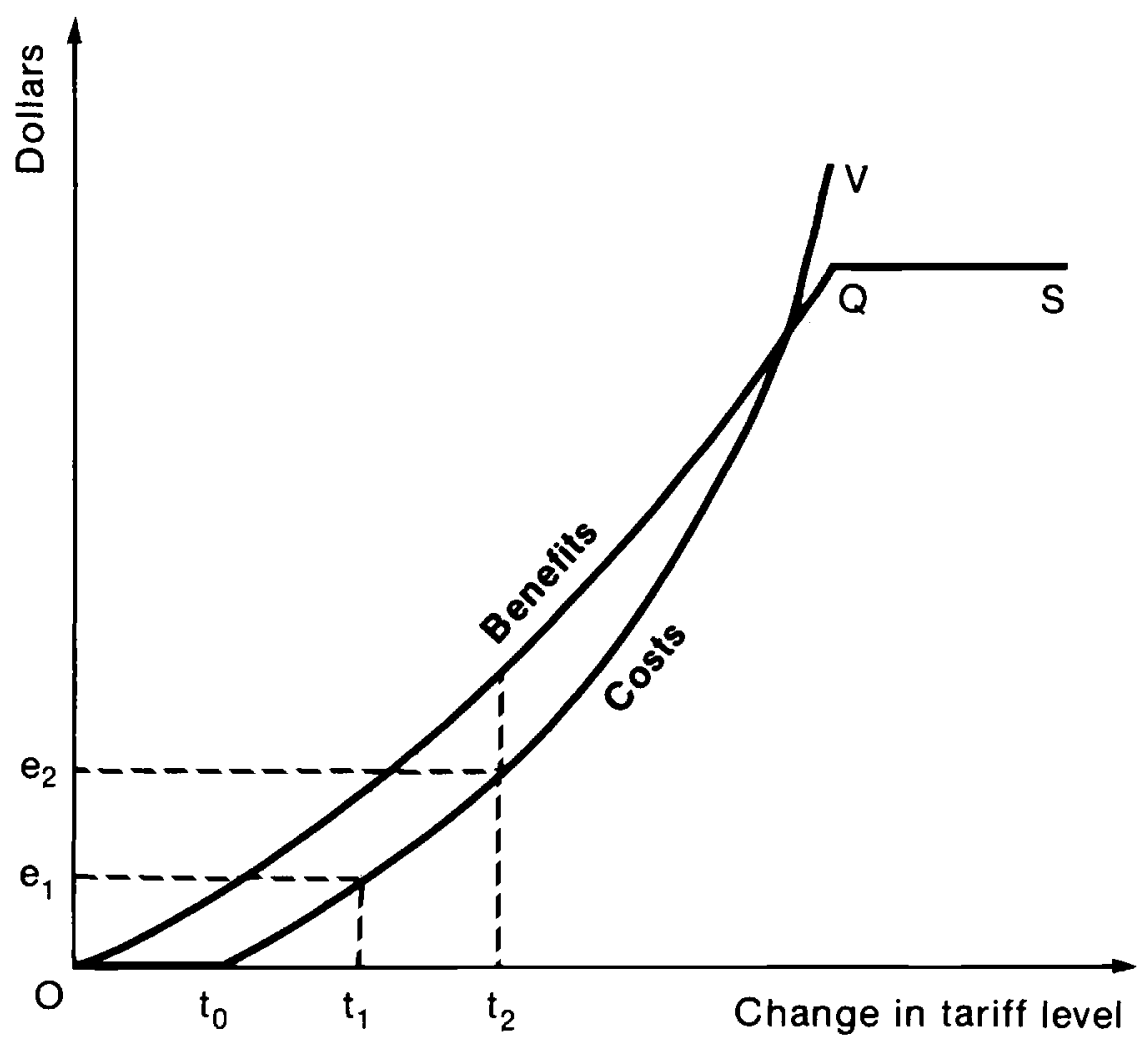

Fig. 10.3

The curve $0 Q S$ in figure 10.3 , on the other hand, reflects the benefits from tariff protection. These are assumed to increase until they level out at $Q$ with maximal protection implied by the prohibitive tariff.

The equilibrium, endogenous tariff then emerges in the usual profitmaximizing fashion. That is, the industry in question will select the particular lobbying-expenditure level at which the additional cost of an increment in the tariff, i.e., the marginal cost of a tariff increase, is just equal to the marginal revenue from the tariff increase. The expenditure level that maximizes the industry's net benefits is $0 e_{2}$ in figure 10.3, and the associated tariff increase is $0 t_{2}{ }^{22}$

Other industries that may or may not be faced with a recent decline in the foreign import supply curve will have similarly shaped gross benefits curves indicating the increase in producer surplus associated with further increases in any existing tariffs and also similarly shaped voter-support curves indicating the highest duty increases obtainable by the industry at 
various expenditure levels. For many industries the voter-support curve may lie entirely above the benefits curve so that no duty change will be supported. Another possibility is that the voter curve, though intersecting the tariff-increase axis at a positive level, rises more rapidly than the benefit curve. In this case the best policy for the industry to follow is not to lobby at all. ${ }^{23}$ It may also be the case that the voter-support curves for different industries are not independent of each voter. For example, if voters have recently supported tariff increases in other industries, the voter-support curve for the industry depicted in figure 10.3 may lie further to the left than if there had not been these increases.

The voter-support curve of an industry receiving protection may also rise over time (and thus lead to a lower optimal tariff increase for the industry) as voters learn from their experiences with a higher tariff. The industry may not live up to its promise to become internationally competitive again or the workers may not appear to be so deserving of assistance as voters learn more about them after the initial duty rise. It is for such reasons that import protection for a particular industry is often only temporary. But the model can also account for indefinite increases in protection. The information disbursed by an industry concerning why it deserves assistance may remain valid indefinitely in the minds of voters or else never be disproved by information from other sources. ${ }^{24}$

Many variations and extensions on the analysis presented thus far suggest themselves. ${ }^{25}$ One would be to introduce various degrees of imperfection in political markets. For example, on the basis of his control of a party's political mechanisms or his greater previous political exposure, the incumbent may be able to obtain a higher duty for an industry than any alternative candidate who is given the same amount of campaign funds. In this case the official will share in the producer surplus generated by the tariff increase by becoming the recipient, say, of campaign contributions that reduce the need for the person to campaign as hard as would otherwise be necessary. Another modification would be to introduce interindustry differences in the ability to raise lobbying funds from firms and workers. Because of the free-rider problem, many industries, for example, may not be able to undertake the expenditures needed to maximize net benefits.

More broadly, investigations are needed concerning the different forms of assistance received by industries. Why is one industry helped by the imposition of quotas while another only receives tariff protection or perhaps extended unemployment insurance? Or why is one industry aided directly by subsidies in various forms and another indirectly by import protection? The reasons the political process does not yield the free trade solution coupled with income transfers to compensate individuals who lose under this policy must also be studied and empirically tested. 
Although this last question is worthy in itself of a separate paper, a few economic and political reasons come immediately to mind. First, under the free trade-income subsidy approach, it would be necessary to set up a costly administrative mechanism both for determining just which firms and what workers are injured by cheaper imports as well as the extent of their income loss and for channeling the appropriate compensation to them. On the other hand, a tariff increase that in part offsets a decrease in import prices partially compensates injured individuals through the operation of the price system. However, the drawbacks of a tariff increase as a compensation means are that it provides extra income for those who may not be very seriously injured by the fall in import prices and does not help those who are too inefficient to remain in the industry with only a partial reversal of the price decline.

The unfavorable experience with actual income-compensating schemes (in contrast to the ideal lump-sum redistribution arrangements assumed in welfare economics) may help account for the failure of the free trade-income subsidy approach to be extensively implemented. For example, there is evidence suggesting that the special unemployment benefits extended to trade-displaced workers in the United States may make employers more willing to lay off workers and may encourage those who do lose their jobs to remain unemployed for longer periods than otherwise. ${ }^{26}$ Such behavior tends to turn both government officials and the general public against this approach. The tariff-raising method also has the deficiency that firms may lay off workers and reduce their efficiency-increasing efforts in the expectation of receiving import protection, but such abuses are probably politically less transparent than those associated with direct income payments.

Gainers from free trade also may be reluctant to support incomecompensating measures because they are unsure of the tax burden they will bear under these schemes. If, in response to a decrease in the price of an import good, a tariff is introduced that completely restores the initial price, a voter whose money income is unaffected by the change knows that he will be no worse off than before the price decline even if he does not receive any of the tariff proceeds. Voters who are risk-adverse may prefer this situation to free trade coupled with an uncertain redistribution scheme that could reduce their real income. Moreover, since it is extremely expensive to levy an income tax that captures part of the consumer surplus gains of just those who benefit from lower import prices, some voters might expect any income subsidy program to be financed through the progressive income tax system used to support most redistributive programs. Those who think they will lose on balance under this arrangement will tend to oppose the free trade-income subsidy approach. A politically appealing feature of increasing the tariff to restore in part the initial domestic price of the imported good is that those 
who gain from cheaper imports pay the costs of partially compensating those who are injured.

Finally, losers from trade liberalization are likely to oppose exclusive reliance on direct income redistribution. Direct income transfers clearly separate the subsidized and productive parts of one's income-receiving activities and tend to demean the recipients. Price-increasing schemes do not seem to be as objectionable to beneficiaries on this ground, since the subsidy element is less transparent. The greater transparency of taxfinanced subsidies to voters is another likely reason for opposition to the free trade-income subsidy approach by those who are injured by free trade. Experience suggests that the duration of voter support for this compensation method is likely to be less than under the tariff-raising approach.

A political-economic analysis of import policy or any other public issue in which various second-best constraints are imposed does not, it should be stressed, mean that discussions of welfare-increasing policies are not longer relevant. Rent-seeking activities are themselves often regarded as a completely wasteful use of economic resources. However, in the political economy model outlined here where the absence of perfect information is a key assumption and where rent-seeking activities mainly take the form of informational expenditures (rather than, say, of incomeredistributing bribes), the matter is not as clear-cut as this. Some of the information provided may be socially valuable from a benefit-cost viewpoint, even though the self-interest goal of an industry leads it to present the type of information that maximizes its likelihood of receiving protection. ${ }^{27}$ Nevertheless, the general public is unlikely to obtain the particular set of information it would prefer to receive from any given level of informational outlays. Levying a tax on the industry's information expenditures and spending the proceeds on the type of information about the industry preferred by the general public would be an example of the kind of policy that could bring about a potential increase in welfare for the majority of voters, who are outside the industry ${ }^{28}$ Moreover, some industries that the community would want to assist if their economic conditions were better known may be unable to organize their members for the purpose of providing such information. As a result, the particular set of industries actually assisted may not be the ones that maximize the welfare of the voting majority for any given magnitude of information expenditures, even if the expenditures made in each industry are of the type desired by the public. Other areas of policy interest involve devising fiscal and institutional mechanisms for selecting and financing the volume of information expenditures that maximizes the community's welfare within the given set of constraints. 


\subsection{Empirical Results: A Review}

The industry characteristics that have been used in empirical efforts to account for industry differences in tariff rates (or changes in these rates) can be divided into three groups: (1) those that indicate the ability and willingness of the productive factors employed in an industry to provide funds and other resources for lobbying efforts; (2) factors that reflect the willingness of the majority of voters and their elected representatives to grant protection; and (3) features that relate to the magnitude of the benefits obtained from different levels of (or increases in) protection. ${ }^{29}$

The first set of factors relate to the voter-support curve $0 t_{0} V$ in figure 10.3 , which indicates the tariff increases voters would support at various levels of lobbying expenditures. However, because of the free-rider problem associated with voluntary lobbying contributions, the feasible range of this curve for the particular industry may be such that the optimum tariff increase cannot be attained. As mentioned earlier, the ability to overcome the free-rider problem and form a common interest group (thus extending the range of the voter-support curve beyond only minimum expenditure levels) is supposedly positively correlated with the degree of industry concentration and negatively related both to the size of the industry in terms of number of firms and to the degree of geographic dispersion. In addition, as Olson (1979) points out, usually a lobbying organization is not formed immediately-or, if the organization already exists, resources are not forthcoming in significant amounts from the membership-upon the emergence of a new common interest for a group. A crisis or repeated series of crises may be necessary to shock the individuals in the group into establishing the organization or increasing their contributions to it. To capture this effect such variables as growth conditions and the level of (or, preferably, the change in) the import penetration ratio have been employed in various regression analyses. In general, the concentration ratio has not been significant in most studies. However, the number of firms, the import penetration ratio, and (especially) measures of growth perform better in the expected manner.

When an industry is subject to greater import competition, the relative change in producer income caused by a given decline as well as the ability of capitalists and workers to move into alternative productive lines may also affect the willingness of those in the industry to contribute to lobbying efforts. The first effect is usually measured by the share of value added in total output and the second by such variables as the average age of the workers, their average wages, an industry's specialization ratio, and the share of capital income in value added. The value-added ratio has turned out as expected in some studies, while among the measures of 
resource flexibility the average wages are almost always highly significant and the average age is significant in most instances. The other measures of resource flexibility do not perform as well. Still another variable influencing the absolute size of lobbying expenditures by an established pressure group is simply its size in terms of the total income of its members. This variable does not turn out to be significant in most regression analyses.

It should be noted that several of the variables affecting lobbying pressures by domestic producers also influence counterlobbying pressures by both foreign producers and domestic consumers. However, the assumption is usually made that the impact of domestic producers dominates that of the other two groups.

Aside from the ability of an industry to undertake lobbying efforts, the shape of the voter-support curve depends upon the willingness of voters and their elected officials to grant import protection. For example, if voters are particularly sympathetic toward low-income workers who suffer income losses and to those who have difficulty in adjusting to income losses, one would expect that tariff rates would be higher (or GATT-related tariff cuts less) in industries with relatively low wages, high proportions of unskilled workers, high average age of workers, etc. However, the higher the growth rate in these industries, the less favorable is the voter likely to be toward a given tariff increase in such industries. Because of attitudes of "fairness" on the part of voters, variables such as the level of import penetration as well as the particular reason for a sudden increase in imports, e.g., dumping, may also influence the shape of the voter-support curve. Voter views on whether an industry's decline jeopardizes some desirable national goal, e.g., national defense or foreign relations with an important foreign country, may also play a significant role in determining the nature of a voter-support curve.

A selfish reason why voters may resist tariff increases is the fear that foreign tariff retaliation will decrease output in the industries where they are employed. Thus one expects increased protection for a particular industry to be easier to obtain if only a few other industries are also pressing for import relief. Similarly, general tariff-cutting efforts by a government are likely to be easier to undertake if other governments are also cutting their import duties. If the majority of voters favor protectionism primarily for selfish, long-run insurance purposes, one would expect this policy to operate mainly in industries where average wages are near those of the voters as a whole on the grounds that these are more similar to the industry for which the average voter wants insurance, namely, his own industry.

The size of the industry in sales or employment terms is likely to affect the voter-support curve for several reasons. Each individual voter real- 
izes, for example, that when the foreign import supply curve is completely elastic in an industry, the producer-surplus benefits obtained from a given import price rise are greater, the greater is the domestic industry's supply. He may also be more willing to grant this price increase, the larger the number of workers per dollar of increase in net benefits. On the other hand, the more significant the protected item is in his budget, the less ready is he likely to be to support increased duties. In addition, industry size influences the curve because of the voting strength of those employed in an industry itself, the magnitude of general tax revenues lost from the declining industry, and the existing degree of knowledge on the part of voters about the sector. The relations of other industries, as import suppliers or output users, to the particular industry under consideration should also be considered in the context of the preceding factors.

Among the variables included in the second group of factors influencing the shape of the voter-support curve, measures of human capital, such as average wages and the proportion of unskilled workers, perform the best and, indeed, seem to be the most significant variables in the various studies taken as a whole. Tests of different international policy variables are not numerous enough to generalize, but Caves (1976) did find some support for Canada's tariffs being related to their economic development goals. Fieleke (1976) on the other hand found that a national defense variable was not significant in accounting for the United States tariff structure. Industry size as measured by number of employees is significant in the expected manner in some of the studies.

Though not included thus far in any of the regression analyses, various factors relating the ability of elected officials to deviate from the preferences of the voters (and still get reelected) could also be included as influences on the shape of the curve indicating the support of decision makers for tariff increases.

The magnitude of the industry benefits from different levels of protection or increases in protective levels, i.e., the position of the producer benefits curve $0 Q S$ in figure 10.3 , depends on the elasticity of the industry's short-run supply curve, the level of output from which tariff increases are being considered, and any other supply curve shifts due to factors other than the initial downward pressure on price. If, for example, productive factors are completely immobile in the short run, the shortrun supply curve will be vertical and the benefits curve will therefore be steeper up to the tariff increase that restores the initial price. This will raise the equilibrium tariff level ceteris paribus. ${ }^{30}$ As already noted, the degree of factor mobility can be measured by such variables as the average wages in an industry, the average age of its employees or, if one considers capital to be more immobile than labor, capital's income share, and the elasticity of substitution of labor for capital in other sectors. 
Furthermore, the higher the degree of product specialization in the industry the more likely it is that a higher proportion of the factors in the industry will be immobile in the short run.

Since a given percentage increase in domestic supply in response to a 1 percent increase in price will increase producer surplus by a larger sum if the initial output level is large, the slope of the benefits curve is also related to the industry's output level. While short-run shifts in the domestic demand curve will not affect the short-run benefits of a given tariff increase in cases where the foreign supply curve is perfectly elastic, these shifts will have an independent price effect when this curve is less than perfectly elastic. An increasing demand curve will add to the short-run benefits of a given tariff increase. Still another factor of this type is the extent to which producers in an industry own comparable facilities abroad that export either back to the home country or to third countries. In the latter case the producers do not wish to set off tariff increases in their export markets.

As the preceding discussion indicates, it is difficult to find variables that enable one to discriminate among different hypotheses concerning the reason for interindustry differences in protectionism. Should, for example, the fact that protectionism is comparatively high in industries with comparatively low per worker levels of human capital be interpreted as support for the hypothesis that voters behave in an altruistic manner or for the hypothesis that, because of their poorer adjustment ability, lowincome groups are more likely to overcome the free-rider problem that tends to limit lobbying efforts? Moreover, quite aside from interindustry differences in voter attitudes or in the free-rider problem, the equilibrium tariff increase after a given decline in the foreign supply curve will be greater if low levels of human capital are associated with inelastic shortrun industry supply curves. One way in which the first two hypotheses might be disentangled would be to determine whether per capita lobbying resources, in terms of money, letter-writing efforts, and other measures of political pressures, on the part of low-wage workers are in fact greater than for high-wage workers in response to a given decline in income. Furthermore, it might be possible to separate the last hypothesis from the others by introducing measures of short-run supply elasticity as well as average wages into the regressions.

Most of the other variables mentioned also can be interpreted as affecting both curves in figure 10.3. The direction of their impact on tariff levels is generally the same, but again existing analyses do not enable one to discriminate among the underlying forces for which these variables serve as proxies. Yet, if one of the objectives of such investigations is to suggest policies or institutional changes that will increase welfare in the second-best world of trade-policy formation, the ability to make such distinctions is essential. The possibility of succeeding in this regard would 
seem to require greater efforts to determine the various separate relationships that make up a total model of the political economy of protectionism.

\section{Notes}

1. The most famous United States historical study along these lines is Taussig (1931). See also Schnattschneider (1935).

2. Several of the articles will be discussed in the text, while all are listed in the references at the end of the paper.

3. Samuelson $(1947$, p. 221$)$.

4. Bergson (1968 reprint, p. 413).

5. Bergson (1968 reprint, p. 413).

6. Arrow (1963, p. 71).

7. Samuelson (1956, p. 15).

8. Arrow (1963, p. 18).

9. Arrow (1963, p. 23).

10. Arrow (1963, p. 106).

11. It has also been pointed out by Coase (1960) that with these conditions some market failures, e.g., certain externalities, will be corrected through private contracts without requiring any government intervention.

12. Arrow (1963, p. 74).

13. The only redistribution generally mentioned relates to the tariff proceeds, and this is not brought into a discussion of attracting additional votes.

14. If workers pursue their self-interest, they will raise tariffs to the levels that eliminate trade. In fact, they could even lobby for export subsidies.

15. See Brock and Magee (1974) for a modeling of some of Olson's concepts in terms of a noncooperative game.

16. One could say that, in these cases, the cost of lobbying is low because it is marginal to a public-good activity already in place.

17. However, the question of what is a "significant section" of the community here can depend, in a pluralistic democracy, on lobbying by the section itself, so that it is not clear that the explanation of protection provided by resort to such a notion as Corden's is truly independent of the kind of explanation resulting from public-choice theory based wholly on self-interest.

18. If the individual's welfare increases, the relationship is one of envy rather than altruism.

19. Arrow (1975, p. 17). Arrow is discussing the reasons why people give blood to individuals they do not personally know.

20. One of the hypotheses tested by Caves on Canadian data is that there is "a collective national preference for industrialization while also promoting prairie settlement and a national transportation system." Caves (1976, p. 279).

21. The diagram assumes the necessary convexities for an interior maximum, of course.

22. If the industry is initially in a tariff equilibrium position but the voters change their views and agree upon a general tariff-cutting rule under a GATT-sponsored trade negotiation, the point $\mathrm{Ot}_{2}$ can be interpreted as the tariff increment above the formula cut that minimizes the industry's losses relative to its initial income level.

23. If the absolute slope of the voter support curve is less at all points than the absolute slope of the non-horizontal portion of the benefits curve, a prohibitive duty will be imposed. 
24. In the narrow self-interest model where voters are in effect tricked into permitting increased protectionism, it is much more likely that the protection to an industry will decline as voters gain experience from repeated "plays" of this political "game."

25. Lobbying-determined tariffs are analyzed, in explicit models, by Findlay and Wellisz (chapter 8) and Feenstra and Bhagwati (chapter 9) in this volume. In fact, Feenstra and Bhagwati develop benefits and costs curves much like those in figure 10.3.

26. See Richardson (chapter 12 here) and Neumann (1979).

27. The appropriability problem may prevent this information from being provided through the private market mechanism.

28. Since these voters would have the option to ask for the same type of information the industry would have furnished with the taxed funds, the ability to select a different information set provides the opportunity for a potential welfare increase.

29. Since the 1930s the average tariff level for dutiable manufactures has decreased very significantly in the industrial countries. For example, in the United States the ratio of duties collected to the value of dutiable imports declined from 59 percent in 1932 to 10 percent in 1970. Consequently, existing interindustry differences in tariff rates are closely related to the ability of industries to resist the general downward pressure on tariffs.

30. Presumably in the initial position the marginal benefits of a tariff increase are less than the lobbying expenditures needed to achieve the tariff increase.

\section{References}

Anderson, K. 1978. Politico-economic factors affecting structural change and adjustment. In C. Aislabie and C. Tisdell, eds., The economics of structural change and adjustment. Institute of Industrial Economics, Conference Series no. 5, University of Newcastle.

- 1979. Toward an explanation of recent changes in Australian protectionism. Mimeographed.

Arrow, K. J. 1951. Social choice and individual values. New York: Wiley.

- 1963. Social choice and individual values. 2d ed. New York: Wiley.

- 1975. Gifts and exchange. In E. S. Phelps, ed., Altruism, morality, and economic theory. New York: Russell Sage Foundation.

Baldwin, R. E. 1976. The political economy of postwar U.S. trade policy. Bulletin, 1976-4, New York Graduate School of Business Administration, Center for the Study of Financial Institutions.

Bale, M. D. 1977. United States concessions in the Kennedy Round and short-run labor adjustment costs: Further evidence. Journal of International Economics 7, no. 2 (May): 145-48.

Bergson, A. 1938. A reformulation of certain aspects of welfare economics. Quarterly Journal of Economics 52 (February): 310-34. Reprinted in 1968 in Alfred N. Page, ed., Utility theory: A book of readings, pp. 402-22. New York: Wiley.

Bhagwati, J. N., and T. N. Srinivasan. 1969. Optimal intervention to achieve non-economic objectives. Review of Economic Studies, vol. 36 (January). 
Brock, W. A., and S. P. Magee. 1974. An economic theory of politics: The case of tariffs. Mimeographed.

- 1978. The economics of special interest politics: The case of tariffs. American Economic Review 68, no. 2 (May): 246-50.

- 1980. Tariff formation in a democracy. In J. Black and B. Hindley, eds., Current issues in commercial policy and diplomacy. London. Macmillan.

Buchanan, J. M., and G. Tullock. 1962. The calculus of consent. Ann Arbor: University of Michigan Press.

Cassing, J. H. 1980. Alternatives to protectionism. In J. Leveson and J. W. Wheeler, eds., Western economies in transition, pp. 391-424. Boulder: Westview Press.

Caves, R. E. 1976. Economic models of political choice: Canada's tariff structure. Canadian Journal of Economics 9, no. 2 (May): 278-300.

Cheh, J. H. 1974. United States concessions in the Kennedy Round and short-run labor adjustment costs. Journal of International Economics 4: $323-40$.

- 1976. A note on tariffs, nontariff barriers, and labour protection in United States manufacturing industries. Journal of Political Economics 84: 398-94.

Coase, R. 1960. The problem of social costs. Journal of Law and Economics 3: 1-44.

Constantopoulos, M. 1974. Labour protection in Western Europe. European Economic Review 5: 313-18.

Corden, W. M. 1974. Trade policy and economic welfare. Oxford: Clarendon Press.

Downs, A. 1957. An economic theory of democracy. New York: Harper \& Row.

Fieleke, N. 1976. The tariff structure for manufacturing industries in the United States: A test of some traditional explanations. Columbia Journal of World Business 11, no. 4 (Winter): 98-104.

Helleiner, G. K. 1977. The political economy of Canada's tariff structure: An alternative model. Canadian Journal of Economics 4, no. 2 (May): 318-26.

Johnson, H. G. 1960. The cost of protection and the scientific tariff. Journal of Political Economics 68, no. 4 (August): 327-45.

- 1965. Optimal trade intervention in the presence of domestic distortions. In R. E. Caves, H. G. Johnson, and P. B. Kenen, eds., Trade, growth, and the balance of payments. Amsterdam: NorthHolland.

Magee, S. 1976. Three simple tests of the Stolper-Samuelson theorem. December, Xeroxed.

Mayer, W. 1974. Short-run and long-run equilibrium for a small open economy. Journal of Political Economics 82, no. 5 (September/October): $955-67$. 
Mueller, D. C. 1976. Public choice: A survey. Journal of Economic Literature 14, no. 2 (June): 395-433.

Mussa, M. 1974. Tariffs and the distribution of income: The importance of factor specificity, substitutability, and intensity in the short and long-run. Journal of Political Economics 82, no. 6 (December): 11911203.

Neumann, G. R. 1979. Adjustment assistance for trade-displaced workers. In D. B. D. Denoon, ed., The new international economic order: The U.S. response. New York: New York University Press.

Olson, M. 1965. The logic of collective action: Public goods and the theory of groups. Cambridge, Mass.: Harvard University Press.

- 1979. The political economy of comparative growth rates. Mimeographed.

Pincus, J. 1972. A positive theory of tariff formation applied to nineteenth century United States. Ph.D. thesis, Stanford University.

- 1975. Pressure groups and the pattern of tariffs. Journal of Political Economics 83, no. 4 (August): 757-78.

Rawls, J. 1971. A theory of social justice. Cambridge, Mass.: Harvard University Press.

Ray, E. J. 1979. Tariff and nontariff barriers to trade in the U.S. and abroad. October, Xeroxed.

Riedel, J. 1977. Tariff concessions in the Kennedy Round and the structure of tariff protection in West Germany: An econometric assessment. Journal of International Economics 7, no. 2 (May): 133-43.

Samuelson, P. A. 1947. Foundations of economic analysis, chap. 8. Cambridge, Mass.: Harvard University Press.

- 1956. Social indifference curves. Quarterly Journal of Economics 70, no. 1 (February): 1-22.

Schattschneider, E. E. 1935. Politics, pressures, and the tariff: $A$ study in free private enterprise in pressure politics, as shown in the 1929-1930 revision of the tariff. New York: Prentice-Hall.

Stolper, W., and P. A. Samuelson. 1941. Protection and real wages. Review of Economic Structure 9, no. 1 (November): 58-73.

Taussig, F. W. 1931. The tariff history of the United States. Cambridge, Mass.: Harvard University Press.

\section{Comment Stephen P. Magee}

Most blind men who have examined the elephant of political economy have come away with different impressions of the animal. My substantial

Stephen P. Magee is the McDermott Professor of Finance at the University of Texas at Austin. He is the author of International Trade and Distortions in Factor Markets (MarcelDekker, 1976) and International Trade (Addison-Wesley, 1980). 
agreement with Baldwin's views leads me to worry that we are either both looking through a glass darkly or both specializing in the same corner of the beast. Since there are so many areas of agreement, this discussion will be limited to the few issues on which we disagree.

Baldwin is skeptical, and properly so, about the Downsian view that competitive markets plus efficient political bribing lead to Pareto optimality. He does a nice job of relaxing the rather restrictive assumptions of this model in the process of attempting to explain tariffs. He is overly optimistic, however, in his reintroduction of social values and interpersonal effects. The Corden "conservative welfare function," Arrow's "altruism," and the Phelps "generalized regard for human rights" models all culminate in the "insurance theory of tariffs." According to this view, government policy on protection provides an insurance policy for riskaverse economic agents. The result is back-door Downsianism: Pareto optimality somehow emerges from rent seeking by protectionist and free trade forces. To my way of thinking, this approach places excessive credence in the potential optimality of rent seeking. There are seven reasons why I believe that this "public welfare view of tariff setting" is a myth.

First, such a view can be defended by appeal to the Coase theorem. When applied to the tariff problem, the theorem asserts that with welldefined property rights, competitive rent seeking by pro- and antitariff forces will lead to Pareto optimality. The fallacy in this view is the failure to see that the legal rules of the game themselves are established by a rent-seeking process. If there are differential costs to groups in setting up the rules of the game, we will observe subsequent competition on issues such as protection resulting in one group in society gaining less than other groups give up.

Second, political markets in information are notoriously imperfect. Successful politicians are frequently those most capable of distorting the views of their opponents to voters: Lyndon Johnson's characterization of Goldwater and Richard Nixon's description of Richard McGovern are cases in point. The manifestation of this behavior in United States discussions of protectionism is illustrated by the protectionist appeal that "tariffs protect jobs." Protectionists do not advertise that tariffs in the United States protect lousy jobs at the expense of good jobs, just as free traders fail to mention that United States tariffs are progressive, benefiting low-wage labor.

Third, Baldwin feels that one failure of elected representatives is that they do not always act in the interest of voters. Though Baldwin discusses Arrow's impossibility theorem earlier, he should have mentioned it here since some patterns of underlying preferences make it impossible to determine the "interest of voters." A related point is that there are situations in which the more competitive the political system, the more 
likely the parties are to sell distortionary policies to well-organized interest groups. The proceeds of such sales are used to improve the party's chances of election (see Brock and Magee 1980).

Fourth, there are empirically indistinguishable alternatives to the insurance theory of tariffs as explanations of both old industries and industries with market power. The low opportunity costs of lobbying activity for low-wage labor and factors in markets with distortions suggest why we would see protection in these industries. Furthermore, the insurance theory is better applied to dumping laws than to tariffs. The theory would suggest that we should observe the rapid application of temporary protection to industries in which unanticipated changes have occurred in world prices. Unfortunately for the theory, (1) this occurrence is also explained by the low opportunity cost of lobbying for unemployed resources and (2) the protection is seldom temporary.

Fifth, the insurance model cannot explain why political markets appear to prefer voluntary export restraints by foreigners as first-best, quotas as second-best, tariffs as third-best, production subsidy as fourth-best, and labor subsidy as fifth-best when unexpected price changes cause wages to fall in certain sectors. Bhagwati (1971) showed that exactly the reverse ranking would hold if the system were operating on the basis of welfare efficiency. The view Brock and I have developed is that redistributive policies are the prices which clear political markets between competing groups. Each party selects policies which maximize its probability of election. In equilibrium, they will have balanced the marginal positive effects of the resources they collect against the negative general voter effect emanating from the general disaffection the distortionary policy generates. This means that each party will select a policy achieving redistribution which is the most indirect and difficult for the voters to understand.

Sixth, I think an underemphasized explanation of protection is that it protects distortionary rents which have been developed through local monopoly power. If the steel industry is imperfectly competitive and earns supernormal profits, labor unions attempt to force management to share these rents. The result is high wages, unionization, and barriers to entry in the factor market for this industry. When imports threaten to reduce the output of the domestic steel industry, the monopoly profits accruing to management and the distorted wage differentials earned by labor stimulate both factors to act in concert. The distortions reduce the mobility of factors in as well as out of the industry. This generates Cairnesian-type lobbying behavior rather than the more traditional Stolper-Samuelson lobbying. Stolper and Samuelson suggest that all capital would be, say, for free trade while all labor would be for protection (or vice versa): their main point is that some labor should not be for protection and other labor for free trade. An empirical test of the Cairnesian 
versus the Stolper-Samuelson approach indicates that nineteen out of twenty-one industries lobbying on the President's trade bill in 1973 followed the Cairnesian approach (Magee 1980a). In a two-factor world, if we plot the positions of capital and labor in a $2 \times 2$ table, we should find all of the observations in the diagonal cells if the world behaves in a Cairnesian (noncompeting group) fashion. If the Stolper-Samuelson model is correct, all the observations would be in one of the two offdiagonal cells. Notice in figure C10.1 that nineteen of the twenty-one industries studied fell along the diagonal, which rejects the StolperSamuelson model.

Seventh (and finally), competitive political markets show considerably more concern over redistribution than over the social welfare issues. What is best for society is much less important than which groups in society can most effectively channel their desire for larger amounts of income into effective political clout. Analysis of United States tariffs on directly competitive imports in 1971 indicates that the social costs are only about 7 percent of the consumer loss. Furthermore, when the stakes are high on both sides (for free traders and protectionists) and when elections are close, large amounts of resources can be channeled into rent seeking with considerable loss (see Magee 1980b).

\begin{tabular}{|c|c|c|c|}
\hline & & $=\mathrm{Po}$ & abor - \\
\hline & & Protectionist & Free Trade \\
\hline $\begin{array}{c}\mid \\
\text { Position } \\
\text { of } \\
\text { Capital }\end{array}$ & Protectionist & $\begin{array}{l}\text { Distilling } \\
\text { Textiles } \\
\text { Apparel } \\
\text { Chemicals } \\
\text { Plastics } \\
\text { Rubber Shoes } \\
\text { Leather } \\
\text { Shoes } \\
\text { Stone, Etc. } \\
\text { Iron/Steel } \\
\text { Cutlery } \\
\text { Hardware } \\
\text { Bearings } \\
\text { Watches }\end{array}$ & Tobacco \\
\hline & Free Trade & Petroleum & $\begin{array}{l}\text { Paper } \\
\text { Machinery } \\
\text { Tractors } \\
\text { Trucks } \\
\text { Aviation }\end{array}$ \\
\hline
\end{tabular}

Fig. C10.1 A classification of twenty-one United States industries according to the political preferences of capital and labor. Source: Magee (1980a). 
To summarize, the issue in competitive rent seeking is whether virtue and optimality emerge or whether the economy is shoved toward a black hole. While some may argue that the horse race is a close one, I'll put my money on the sow's ear over the silk purse.

\section{References}

Bhagwati, J. N. 1971. The generalized theory of distortions and welfare. In J. N. Bhagwati et al., eds., Trade, balance of payments, and growth, pp. 69-90. Amsterdam: North-Holland.

Brock, W. A., and S. P. Magee. 1978. The economics of special interest politics: The case of the tariff. American Economic Review Papers and Proceedings 68 (May): 246-50.

- 1980. Tariff formation in a democracy. In J. Black and B. Hindley, Current issues in international commercial policy and diplomacy, pp. 1-9. London: Macmillan.

Magee, S. P. 1980a. Three simple tests of the Stolper-Samuelson theorem. In P. Oppenheimer, Issues in international economics, pp. 138-53. London: Routledge \& Kegan Paul.

. $1980 b$. The black-hole theory of competitive rent seeking. Department of Finance, University of Texas at Austin, mimeographed.

\section{Comment Stanislaw Wellisz}

In recent years trade economists' interests have increasingly shifted from welfare economics to the political economy of trade and protection. The older line of inquiry dealt primarily with comparative statics and focused on the first best, while admitting obstacles to its achievement. ${ }^{1}$ The newer one concentrates on adjustment processes and is the economics of the second best par excellence. More important perhaps is the treatment of the institutional framework. Trade economists (Marxians excepted) tended to treat institutions as a datum. They now attempt to endogenize the trade regime by modeling the political process. Baldwin, who himself made important contributions to the welfare discussion, ${ }^{2}$ now gives us an excellent survey of the political economy of trade. The survey brings together many strands of thought, clarifies difficult issues (I especially appreciate the lucid interpretation of Brock and Magee), and provides a valuable background to the papers presented at this conference.

Baldwin starts by comparing the Bergson-Samuelson with the Arrow social welfare function. The former treats social welfare as an ordering of

Stanislaw Wellisz is professor of economics at Columbia University. He has made contributions to developmental theory, the theory of organization of the firm, and international economics (jointly with Ronald Findlay). His publications include The Economics of the Soviet Bloc (New York: McGraw-Hill). 
individual utilities performed by a grand ranker with his own preferences. The latter views social welfare as a mapping from individual to aggregate preferences. The inherent difficulties of these formulations need not detain us here. It may be worthwhile to point out, however, that the former corresponds to the conception of the government as a guardian of public interest, whereas under the latter the government is merely an executor of the resultant of individual or collective pressures.

The distinction between the two concepts of the social welfare function helps clarify some of the models discussed by Baldwin. Thus we may pose ethical questions to a Bergson-Samuelson type of government, but not to one of the Arrow type; conversely, we may ask how voting, lobbying, or for that matter the use of force explains the actions of the latter, but not of the former. But too much discussion of the nature of the social welfare function is counterproductive. It is idle to speculate why some interests helped by changes in trade patterns favor redistribution in favor of those who are hurt by the change. Those willing to give might be genuinely altruistic, or the poverty of others might constitute for them a negative externality, or they might follow an insurance principle (their "altruism" will be reciprocated in case of need), or maybe they think that if they do not yield a little voluntarily, more will be taken from them by force. Clearly, speculation as to the motives does not help our understanding or ability to predict the outcome.

The most significant progress made by the political economists of trade does not result from speculation about the nature of welfare functions, but from the consideration of problems affecting specific interest groups. The familiar $2 \times 2$ model tells us that if changes in trade patterns help one factor (such as capital), they are likely to hurt another (such as labor). Such a broad formulation throws little light on the pattern of interest groups in a world in which there is human as well as physical capital and where, in the short run, either type of capital may be highly specific. The new analysis helps us understand why, often, capital, management, and labor engaged in a given industry join forces in lobbying for or against protection. In the long run United States capital (or is it labor?) will benefit from increased foreign car competition. Right now the owners of specific capital employed in that industry, which means the stockholders, and various kinds of labor, including management and union leaders, are hurt: owners of specific factors do unite.

By the same token economists have retreated from policy descriptions derived from analytically illuminating, but overly simplified, models. Thus the maximization of social welfare subject to the constraint that employment of a factor be maintained on a specific level (or, by the same token, that the income of a specific factor be maintained on a given level) leads to the conclusion that a tax-cum-subsidy scheme is superior to tariff protection. ${ }^{3}$ Now that the United States government is taking such direct 
compensatory steps (many other governments have done so before, and failed) we begin to realize how difficult it is to determine in practice who is hurt by changes in trade patterns.

Direct subsidization leads to a host of difficulties which can be broadly subsumed under the moral hazard label. The reliance on old-fashioned trade restraints, for all the inefficiencies they create, at least avoids that difficulty.

For all the progress we have made, our knowledge of the political economy of trade is still in its infancy. The observed pattern of trade restraints is compatible with any number of hypotheses concerning the nature of political processes. The reality, which has so long eluded the analysis of political scientists, has yet to yield its secrets to the investigation of economists armed with more powerful analytic tools. Likewise, our understanding of specific restrictive measures is also rather weak. When confronted with the question, why tariffs, or why quotas, or why voluntary restrictions, we beat a hasty retreat from analytic to commonsense explanations. Yet if we hope to improve policy-and, after all, we are all moralists at heart-we should have a clear understanding of the factors dictating the current practice.

Baldwin's survey is doubly valuable: it shows what we have accomplished and what is yet to be done. We may be humbled by how little we have accomplished, but, unlike Alexander, we need not despair that nothing is left to conquer.

\section{Notes}

1. For a classic statement, see Samuelson (1962).

2. In particular, see Baldwin (1952, 1953-54).

3. For an elegant proof of such propositions, see Bhagwati and Srinivasan (1969).

\section{References}

Baldwin, R. E. 1952. The new welfare economics and gains in international trade. Quarterly Journal of Economics 65: 91-101.

- 1953-54. A comparison of welfare criteria. Review of Economic Studies 21: 154-61.

Bhagwati, J. N., and T. N. Srinivasan. 1969. Optimal intervention to achieve non-economic objectives. Review of Economic Studies 36: 27-38.

Samuelson, P. A. 1962. The gains from international trade once again. Economic Journal 72 (December): 820-29. 